\title{
KAJIAN KERUSAKAN DAN KERUNTUHAN TUBUH BENDUNG AKIBAT PENGARUH BANJIR (STUDI KASUS : BENDUNG CIPAMINGKIS KAB. BOGOR)
}

\author{
Heri Suherlan \\ Program Studi Magister Teknik Sipil, Universitas Sangga Buana \\ korespondensi: herisuherlan.st@gmail.com
}

\begin{abstract}
The land used in the area around the Cipamingkis sub-watershed is very intensive, it is feared that there will be damage to the land which has an impact on the decline in fertility and soil carrying capacity, resulting in the danger of flooding, landslides and even erosion during the rainy season. In this study, there are 2 approach concepts, namely qualitative and quantitative, as well as examining the relationship between one variable and another. Methods of data collection process include questionnaires, interviews, documentaries, and samples taken from the community around the Cipamingkis River. The analysis results from the research that the damage to the previous weir location, the plan for the new weir location must be moved to the upstream location of the old weir which has a relatively flat channel bottom by considering the intake elevation for the irrigation channel face, and the old weir building is proposed to be rebuilt as a Groundshill building for irrigation. withstand the current of water velocity. Consideration of the old design must be changed by taking into account the part of the forces that affect the stability of the weir, bore pile and the quality of the concrete as a consideration.
\end{abstract}

Keywords : DAS, DAM, Cipamingkis, Flood, Erosion

\begin{abstract}
ABSTRAK
Lahan yang digunakan didaerah sekitar Sub DAS Cipamingkis sudah termasuk sangat intensif, dikhawatirkan akan terjadi kerusakan pada lahan yang berdampak kepada penurunan pada tingkat kesuburan, dan daya dukung tanah, sehingga mengakibatkan bahayanya banjir, longsor bahkan erosi pada musim hujan. Pada Penelitian ini mempunyai 2 konsep pendekatan yaitu kualitatif dan kuantitatif, serta mengkaji hubungan tiap satu variable dengan yang lain. Metode proses pengumpulan data mencakup metode Kuesioner, wawancara, documenter, dan sampel diambil dari masyarakat di sekitar Sungai Cipamingkis. Hasil analisis dari penelitian bahwa kerusakan lokasi bendung sebelumnya, rencana untuk bendung baru lokasinya harus pindah ke lokasi hulu bendung lama yang relatip mempunyai dasar saluran datar dengan mempertimbangkan elevasi intake untuk muka saluran irigasi, dan bangunan bendung yang lama diusulkan diperbaiki kembali menjadi sebagai bangunan Groundshill untuk menahan arus kecepatan air. Pertimbangan terhadap desain lama harus dirubah dengan memperhitungkan bagian gaya-gaya yang mempengaruhi kestabilan bendung, boor pile dan kualitas beton sebagai pertimbangannya.
\end{abstract}

Kata Kunci : DAS, Bendung, Cipamingkis, Banjir, Erosi.

\section{PENDAHULUAN}

Sistem bio-fisik lahan Daerah Aliran Sungai (DAS) memiliki banyak fungsi yaitu fungsi produksi, fungsi habitat, fungsi ekologi dan juga fungsi estetika. Umumnya sudah begitu luas dalam pemanfaatan sumber daya air yang sejalan dan dengan berkembangnya pada pembangunan pada daerah sumberdaya air.
Peningkatan masyarakat membuat daerah aliran sungai (DAS) menampung beban yang berat dan terjadinya alih fungsi. Kemudian eksploitasi sumberdaya alam ayang meningkat nyatanya secara intensif menyebabkan degradasi pada kondisi DAS dan akan berdampak pada penurunan kualitas 
air yang akan menyebabka terjadinya bencana disekitar DAS meningkat.

Pada suatu sistem sungai (river basin) merupakan komponen drainase utama pada basin yang berhubungan. Bentuk dan ukuran alur sungai alamiah, berkaitanya dengan drainase, dan merupakan bentuk yang sesuai dengan kondisi geologi, geografi, ekologi dan hidrologi daerah tersebut. Bentuk-bentuk ini berfungsi untuk menahan air supaya tidak cepat mengalir ke hilir dan menahan sedimen [1].

Pada daerah hulu sungai Cipamingkis, keadaan hutan lindungnya cukup menghawatirkan karena adanya perubahan akibat adanya alih fungsi pada hutan. Hal ini diakibatkan kerena pengambilan lahan dan pemanfaatan hutan yang tidak bertanggung jawab. Lahan pada sekitar Sub daerah aliran sungai Cipamingkis sudah terlihat banyaknya kerusakaan pada sisi tebing sungai, dan terjadi longsoran talud disepanjang DAS terutama di musim hujan, serta erosi.

Erosi aliran permukaan terjadi jika intensitas lamanya hujan dan melebihi kapasitas infiltrasi atau kapasitas simpan air tanah. Aliran Permukaan yang terjadi tidak merata dan tidak beraturan, maka kemampuan untuk mengikis tanah juga tidak atau tidak merata untuk semua tempat [2]. Selain itu akan menyebabkan penurunan pada debit air yang dimana kurangnya air tanah ketika kemarau Penambangan material berupa pasir kerikil batu bolder yang merupakan masuk pada golongan $\mathrm{C}$ secara besar-besaran semenjak dibangun bendung sampai kini dilokasi disepanjang Daerah DAS Cipamingkis banyak sekali dimanfaatkan masyarakat untuk bahan bangunan. Pada akhirnya kegiatan ini berakibatkan pada berkurangnya lapisan pada dasar sungai, dan lapisan lunak pada bagian bawah sudah nampak dan akan berakibatan pada penuruan di dasar sungai atau degradasi. Pada akhirnya kesetabilan bendung Cipamingkis dan juga bangunan lainnya yang disekitar sungai jadi terkena dampak.

Pengaman Dasar Sungai (PDS) lengkap dengan mercu dan peredam energinya sudah dibangun sebanyak 9 buah dalam upaya mengurangi proses degradasi, tetapi seluruh PDS hancur akibat ketidak mampuan dalam menahan prosesnya degradasi dan debit banjir yang terus meningkat. Hal ini disebabkan karena adanya kerusakan lingkungan di Sungai Cipamingkis. Sehingga penelitian ini bertujuan untuk mengembalikan kondisi semula dengan penataan lahan kembali dari beberapa faktor penyebab kerusakan baik yang disebabkan oleh alam atau perilaku kehidupan manusia dan memberikan konsep pengendalian menuju sungai yang dinamis yang tidak memberikan suatu kerugian terhadap rusaknya sarana prasarana yang ada.

\section{TINJAUAN PUSTAKA}

Debit/aliran merupakan volume air yang mengalir melalui sebuah penampang yang melintang dalam alur (channel), pipa, akuifer, ambang dan sebagainya, dalam satuan waktu. Limpasan adalah semua air yang bergerak kearah luar dari daerah pengaliran ke sebuah 
aliran permukaan (surface stream), dan tidak melihat rutenya, apakah lewat rute permukaan atau lewat di bawah permukaan tanah (surface atau subsurface). Limpasan terdiri dari 5 jenis, yaitu limpasan permukaan, limpasan dibawah permukaan, limpasan bulanan, limpasan tahunan dan limpasan rata-rata bulanan dan tahunan [3].

Pada tempuran / pertemuan atau disebut juga confluence antara anak sungai dan induknya, jarang terjadi datangnya puncak-puncak hidrograf dari kedua sungai pada waktu bersamaan. Hidrograf anak sungai yang memiliki DAS lebih sempit dan curam, berfluktuasi lebih cepat, dan pada puncak hidrografinya juga datang lebih cepat setelah jatuh hujan. Karena curamnya kelandaian aliran, sebagian sedimen yang terbawa ke tempuran dari anak sungai tidak akan dapat dibawa oleh sungai induknya yang lebih landai, dan mengendap sebagai beting pasir atau shoal di situ. Beting pasir ini lama kelamaanakan membesar dan menimbulkan backwater positif di hulunya dan lereng aliranyang curam di hilirnya (bukan backwater negatif) [4].

Bendung terdapat beberapa klasifikasi berdasarkan tipe konstruksi, diantaranya yaitu bending tetap, Bendung in tidak dapat mengatur tinggi dan debit air dari sungai, kemudian bendung gerak yang dipergunakan untuk mengatur tinggi dan debit air sungai dengan pembukaan pintu-pintu yang terdapat pada bendung tersebut, dan juga bending kombinasi, yang berfungsi sebagain bendung tetap dan gerak [5].

\section{METODE PENELITIAN}

\section{Proses Penelitian}

Pada proses penelitian, acuan yang digunakan yaitu dengan metodologi kerangka berpikir [6]. Langkah - langkah dari penelitian ini beracuan dari pendekatan secara sistematik yang terintegrasi dari observasi dilapangan yang bertujuan untuk mengidentifikasi permasalahan, rumusan masalah dan juga menentukan batasan pada penelitian. Pada kerangka teoritis diidentifikasi variable pada penelitian dan juga hubungan perumusan hipotesis, ynag rancangan penelitin ini untuk mengumpulkan dan pengolahan data, kesimpulan dan saran sebagai rekomendasi pada penelitian selanjutnya

\section{Metodologi Yang Digunakan}

Dalam sebuah metode harus tersusun secara sistematis yang artinya proses yang menggunakan langkah-langkah tertentu [7] Metode penelitian dibagi menjadi tiga macam metode yaitu, penelitian Eksperimen, penelitian Survey dan penelitian Naturalistik.

\section{Pendekatan Kualitatif dan Kuantitatif}

Penelitian ini mempunyai 2 konsep pendekatan yaitu kualitatif dan kuantitatif. pendekatan kualitatif sendiri merupakan metode penelitian bersifat deskriptif, cenderung juga mencari sebuah makna ataupun arti dari sebuah data yang diperoleh dari hasil sebuah penelitian [8] Sedangkan pendekatan secara kuantitatif adalah penelitian yang sistematis, dengan terencana yang terstruktur dari awal hingga penyusunan penelitian [9]. 


\section{Variabel Penelitian}

Pada dasarnya pada veriable penelitian merupakan bentuk apa saja yang ditentukan oleh peneliti untuk dipelajari na memberikan informasi terkait hal tersebut, lalu diambil kesimpulan [10]. Peneliti mengkaji hubungan tiap satu variable dengan yang lain dan dibedakan dalam 2 variable, yaitu :

a. Variabel Terikat (Dependent Variable), dalam penelitian ini yang menjadi variabel terikat adalah banjir.

b. Variabel Bebas (Independent Variable), dalam penelitian ini yang menjadi variabel bebas adalah kerusakan dan keruntuhan tubuh bendung.

\section{Populasi dan Sampel}

Populasi dalam penelitian yang akan dilakukan adalah masyarakat di sekitar Sungai Cipamingkis. Pada penelitian ini diambil sampel yaitu masyarakat di sekitar Sungai Cipamingkis. Dari masyarakat sekitar Sungai Cipamingkis tersebut selanjutnya ditetapkan jumlah minimum dengan cara perhitungan pada statistic proporsional yaitu :

$N=10 \% \times P$

Dengan :

$\mathrm{N}=$ Banyaknya responden minimum

$\mathrm{P}=$ Jumlah masyarakat sekitar Sungai Cipamingkis

\section{Teknik sampling}

Teknik sampling yang digunakan dalam penelitian ini adalah disproportionate Stratified Random Samplig, dimana teknik ini digunakan untuk menentukan jumlah sampel, bila populasi berstrata tapi kurang proporsional.

\section{Sumber Data Penelitian}

Data yang dikumpulkan untuk keperluan kajian ini terbagi menjadi 2 yaitu :

a. Data Primer

Data primer yaitu data yang diperoleh langsung dari hasil Survey ke lokasi Kejadian keruksakan atau hasil wawancara maupun dari jawaban hasil pengisian kuisioner tentang factor penyebab keruksakan bendung, dan data dari diperoleh wawancara dengan beberapa petugas bendung yang ada dilapangan

b. Data Sekunder

Data sekunder adalah data atau bahanbahan serta dokumen yang diperoleh lewat pihak lain ,dari data konsultan, dokumen BBWS Citarum, Pusat Penelitian dan Pengembangan Air (PUSSAIR), PJT II, Badan Pusat StatistikpPropinsi Jawa Barat (BPS), Badan Perencanaan Pembangunan dan dari berbagai informasi lain yang terkait seperti hasil kajian terdahulu.

\section{Metode Proses Pengumpulan Data}

Data penelitan yang dikumpulkan adalah:
a. Metode Kuesioner
b. Metode Wawancara
c. Metode Dokumenter 


\section{Metode Proses Pengolahan Data}

Data didapatkan berupa survey yan dianalisis untuk memberikan informasi. Proses pengolahan data dengan cara :

a. Analisis presentase

b. Skala pengukuran/ penentuan skor

c. Transformasi data ordinal menjadi interval

d. Analisis jalur

\section{Kuesioner Penelitian}

Tujuan dari kuesioner ini untuk mencari pendekatan mengenai tingkat kerusakan

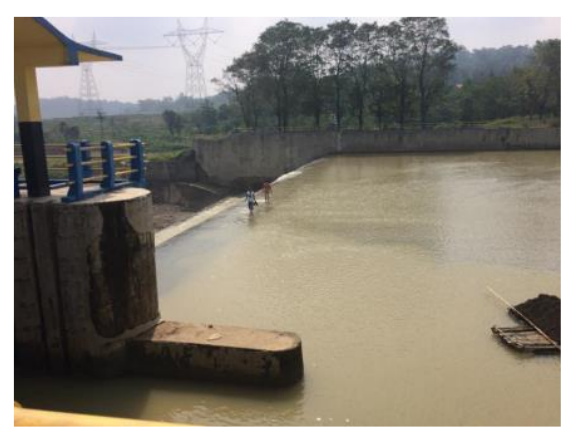

Gambar 1 : Kondisi Bendung sebelum terjadi banjir relative baik dan tidak ada masalah

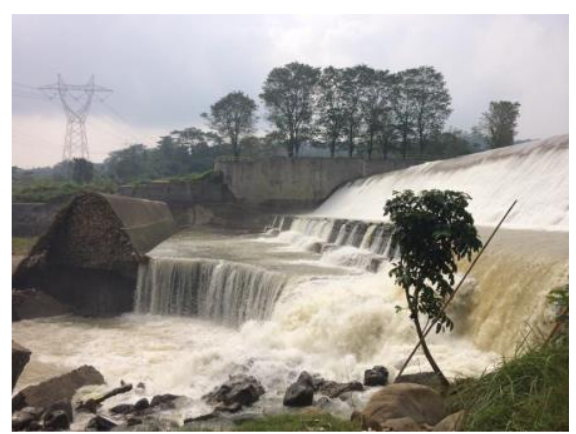

Gambar 2 : Kondisi Mercu Utama (Cascade ke-1) masih utuh dan tidak mengalamin kerusakan

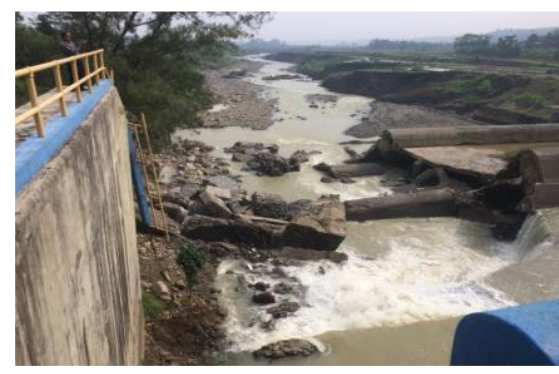

Gambar 3 : Kondisi Mercu ke-2 dan ke-3 sudah pecah pada sisi kiri sepanjang \pm 15 meteran setelah banjir 
Kondisi Jembatan Inspeksi sebelah hilir bending terputus karena ada sebagian badan wing wall dari bendung yang pecah dan longsor. Kondisi Intake Bendung masih utuh dan tidak mengalami kerusakan. Kondisi
Induk Cibarusah masih utuh secara kasat mata, namun perlu diselidiki lagi karena pada jalan inspeksi sebelah kanan saluran terdapat longsoran yang cukup dalam \pm 2 meteran.

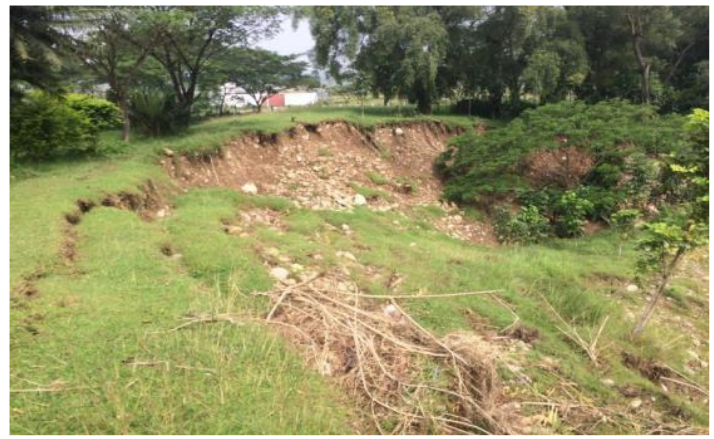

Gambar 4 : Kondisi Hilir Bendung sebelah kiri terdapat longsoran dari wing wall kiri bending ke arah hilir bending sepanjang $\pm \mathbf{1 0 0}$ meteran, serta terdapat bangunan instalasi didekat bending yang terkena dampak longsoran, bangunan tersebut lonsor sedalam \pm 1-2 meteran.

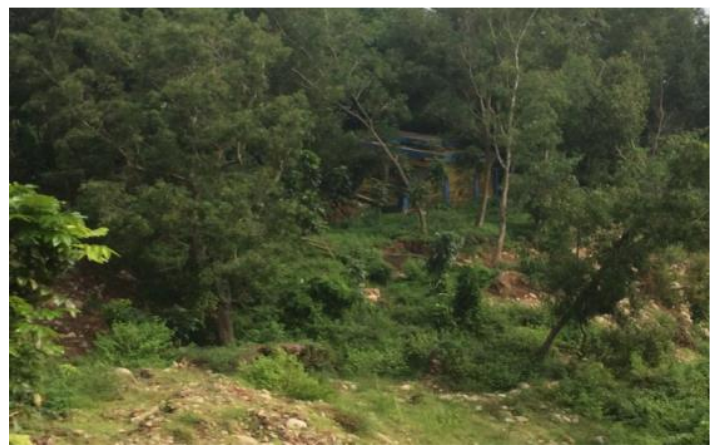

Gambar 5 : Kondisi Sungai pada hilir bending, khususnya pada bawah mercu cascade ke-2 dan ke-3 terdapat gejala dagradasi alur sungai, sehingga perlu penanganan lebih lanjut.

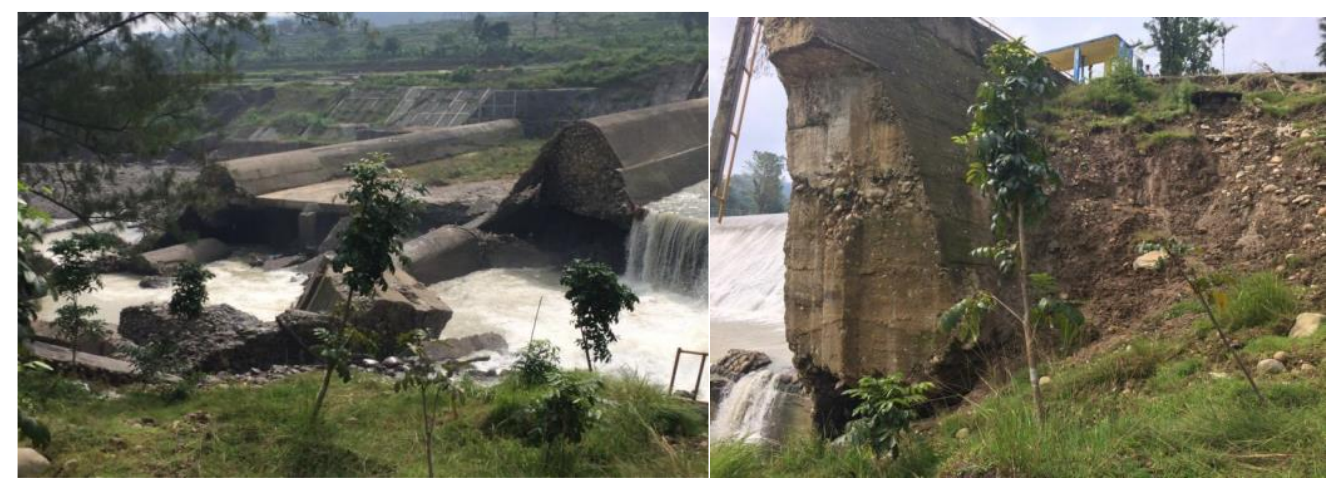

Gambar 6 : Hasil Penangamatan secara kasat mata pada tanah yang mengalami longsoran, kondisi tanah relative lembab dan terdapat aliran-aliran kecil dari pori-pori tanah, hal ini merupakan gejala dari terjadinya piping, sehingga perlu pengamatan lebih lanjut dari penyelidikan geoteknik.

Faktor-faktor Analisis yang Faktor yang menyebabkan yaitu : mempengaruhi kehancuran Bendung. 
1. Adanya bocoran piping karena terjadi melalui bawah struktur Bendung dengan kecepatan yang cukup besar. Partikelpartikel tanah yang ada didasar sungai akan berpotensi menyebabkan kerusakan yaitu keroposnya tanah yang ada dibawah struktur Bendung. Kerusakan dari struktur tanah ini mengakibatkan struktur menjadi pecah atau hancur. Hal yang dilakukan untuk mengatasi dari jenis kerusakan ini yaitu dengan dilakukan cara mengurangi kuat arus piping dengan melakukan :

- Pembikinan lantai muka

- Pembikinan turap

2. Lantai rendah rusakan diakibatkan karena salahnya hitungan atau asumsi atau kurangnya pengujian yang dilakukan terhadap bagian Bendung tersebut. Lantai dapat rusak akibat dari terjadinya turbulensi/olakan (kolk) dari aliran dan dapat ditangani dengan perhitungan dari hidrolika yang tepat, dan juga dalam pembuatan lantai rendah harus disertakan dengan proses pengujian dari kekuatan lantai. Proses pengujian tersebut dilakukan dengan cara mengukur nilai kekerasan lantai dan digunakan bantuan berupa alat uji NDT yang bisa mengukur tingkat kekerasan pada suatu bangunan atau bagiannya.

3. Adanya pecahnya pada badan bendung disebabkan adanya tekanan tarik dan disebabkan juga karena kesalahan dalam desain. Kesalahan ini mengakibatkan resultan gaya yang bekerja yang letaknya diluar teras menjadi terlalu besar. Maka dari itu mengatasinya harus dengan membuat dimensi/bentuk yang akibat dari gaya-gaya yang bekerja pada teras.

4. Gerusan dari pasir/lumpur di bendung, hal tersebut adalah hal yang umum terjadi dan juga terlebih jika sungai sedang mengalami banjir, dan untuk mengatasinya harus menggunakan kekuatan dari beton yang cukup kuat. Gerusan air dengan ketebalalan sekitar kurang lebih $30 \mathrm{~cm}$ cara untuk menahan nya

5. Ketidaksatabilitas terjadi karena adanya tekanan air yang terlalu besar. sehingga tekanan air perlu diperkecil yaitu dengan menggunakan cara memecahkan energy air yang di muka bendung.

\section{Analisis Geologi}

Berdasarkan kajian Laporan Geilogi Teknik yang disusun oleh PT. Arga Paksa Rencana 2012, dapat diidentifikasikan bahwa salah satu faktor yang terkait langsung dengan terjadinya kerusakan bangunan existing berupa bendung, groundsill, tebing sungai dan terjadinya degradasi dasar sungai Cipamingkis dan meningkatnya potensi daya rusak terhadap morfologi sungai Cipamingkis adalah permasalahan geologi. Hal ini disebabkan sifat-sifat batuan yang terdapat di sepanjang aliran sungai Cipamingkis mulai dari hulunya ke hilir yang akan diuraikan sebagai berikut :

a. Jenis batuan yang terdapat di sepanjang alur sungai Cipamingkis di lokasi perencanaan pada umumnya adalah batuan sedimen berumur Tersier yang antara lain terdiri dari : batunapal, batu 
lempung, batu lempung napalan, batu pasir, batu pasir gampingan dan batuan sedimen lainnya. Batuan sedimen berumur Tersier tersebut kemudian ditutupi secara tak selaras oleh endapan aluvium sungai dan kipas aluvial yang terbentuk pada awal Kuarter (Plistosen)

b. Jenis batuan "batuan karbonat" yang ada di lokasi pekerjaan adalah batuan yang secara kimiawi mengandung senyawa $\mathrm{CaCO}_{3}$ yang sangant mudah bereaksi dengan air seperti : batunapal (marlstone), batu lempung napalan (marly claystone), dan batu pasir gampingan (calcareous sandstone). Batuan karbonatan yang secara kimiawi mengandung $\mathrm{CaCO}_{3}$ ini sangant mudah bereaksi dengan air dan udara sehingga terjadi proses pelarutan yang dapat berlangsung dalam skala waktu relatif singkat. Bila tersingkap ke permukaan tanah, maka senyawa $\mathrm{CaCO}_{3}$ pada jenis batuan karbonatan akan bereaksi dengan air dan udara sehingga terjadi proses pelarutan. Proses pelapukan batuan yang menyebabkan terjadinya perubahan sifat fisik batuan di lokasi perencanaan juga akan menyebabkan berkurangnya daya tahan batuan terhadap proses erosi akibat aliran sungai dan sekaligus juga menurunkan daya dukung batuan untuk pondasi bangunan, dimana terjadi pengikisan dan erosi. Pada saat muka air sungai naik sewaktu turun hujan, maka singkapan batuan di tebing sungai sampai ketinggian tertentu akan tenggelam di bawah permukaan air sungai, sedangkan pada waktu muka air sungai surut dan kembali normal maka sebagian dari singkapan batuan tersebut akan berada di atas permukaan air. Karbonat yang kembali muncul di atas permukaan air sungai tersebut akan mengalami proses kimia yang dimulai dengan masuknya gas $\mathrm{CO}_{2}$ yang berasal dari udara kemudian larut dalam air yang terdapat di dalam batuan dan selanjutnya terjadi proses pelarutan pada batuan karbinat tersebut. Setelah proses pelarutan selesai dan batuan mengering karena pemanasan matahari maka selanjutnya terjadi proses pelapukan dimana permukaan batuan akan menjadi kering dan pecah-pecah membentuk lapisan permukaan tanah lapukan yang rapuh dengan ketebalan bervariasi mulai kurang dari 1 milimiter sampai beberapa milimiter, tingkat erosi yang cukup tinggi, kemudian menjadi pemicu bagi kerusakan dasar sungai dan tebing sungai Cipamingkis, sehingga degradasi morfologi sungai berlangsung dengan cepat. Erosi horizontal akan menyebabkan terbentuknya rongga-rongga pada Proses pelarutan dan pelapukan seperti diuraikan diatas telah menyebabkan Bila hujan turun kembali dan air sungai meluap dengan kecepatan arus relatif lebih tinggi maka lapisan permukaan tanah lapukan yang pecah-pecah dan rapuh tersebut akan hanyut terbawa air sungai. Dengan demikian, proses erosi pada singkapan batuan tersebut dapat terjadi pada setiap 
kali turun hujan dengan tebal pengikisan yang dapat dimasukkan dalam kategori terjadinya erosi dengan intensitas yang cukup tinggi, baik erosi secara horizontal ke samping maupun erosi secara vertikal ke dasar sungai, yang bagian bawah dari tebing sungai sehingga menyebabkan longsoran pada lapisan batuan penutup diatasnya dengan jenis "rock fall" atau "debris flow", sedangkan erosi vertikal akan menyebabkan penurunan dasar sungai dengan kecepatan relatif tinggi

c. Perbedaan intensitas penurunan daya tahan dan daya dukung dari masingmasing jenis batuan antara batuan yang satu dengan batuan lainnya dipengaruhi antara lain oleh faktor gradasi besar butir dari batuan dan jumlah kandungan karbonat yang terdapat di dalam batuan. Perubahan atau perpindahan alur sungai terjadi akibat pengaruh sifat fisik batuan yang berbeda yaitu antara batu pasir gampingan yang membentuk tanggul sebelah kiri dan batu napal yang membentuk palung sebelah kanan. Batu napal yang berada di sebelah hulu dengan posisi stratigrafi yang terletak di bawah telah mengalami proses pelarutan batuan yang berlangsung dengan lebih cepat dari pada palerutan lapisan batu pasir gampingan di sebelah hilir dengan posisi stratigrafi yang terletak diatasnya. Perbedan kecepatan pelarutan dari kedua jenis batuan ini juga menyebabkan perbedaan pada daya tahannya terhadap pengikisan oleh aliran sungai. Pengikisan atau erosi yang terjadi pada batu napal berjalan dengan lebih cepat dari pada batu pasir gampingan, yang menyebabkan penurunan dasar sungai pada batu napal terjadi lebih awal dari pada yang terjadi pada batu pasir gampingan sehingga penurunan dasar sungai di bagian hulu lebih cepat dari pada bagian hilir. Hal ini telah menyebabkan terbentuknya tanggul alam yang melintang dan memotong aliran sungai sehingga aliran sungai berpindah dan berbelok mengikuti arah tanggul yang dibentuk oleh batu pasir gampingan tersebut

Hasil Analisa Faktor Kehancuran Bendung Akibat Dari Kondisi Geologi/Mekanika Tanah Yang Ada disekitar Bendung Sungai Cipamingkis.

Kerusakan pada konstruksi bangunan bendung, baik pada bendung maupun pada perkuatan tebing atau tanggul Sungai diawali proses secara alamiah terjadi pelarutan pada batuan dasarnya dimana batuan yang ada di sekitar Sungai ini mengalami pelarutan dan pelapukan dimana di Sungai tersebut adanya penggalian material disepanjang sungai sehinnga mengakibatkan terbentuknya perubahan Morfologi dan penurunan dasar Sungai atau degradasi dan bila terjadi banjir batuan yang tersikap terbawa aliran yang mengakibatkan terjadinya erosi

Lubang yang terbentuk di bawah pondasinya dimulai proses pelapukan batuan dasar yang berkembang semakin luas dalam waktu relatif cepat akibat dari proses pelarutan batuan juga dipercepat oleh pengaruh olakan air yang 
terjadi karena adanya kolam olak/ endsill yang menyebabkan putaran arus sungai disekitar hilir bendung.

\section{Analisa Topografi}

Titik lokasi bending exsisting berada di slope kemiringan yang tajam, hal ini bending tersebut terdapat 3 (tiga buah Mercu) dan olakan, beda tinggi elevasi lebih dari $8-12 \mathrm{~m}$, hal ini mengingat perletakan lokasi bendung tersebut salah satunya sesuai dengan elevasi tangkapan air intake irigasi. Analisa terhadap ketersediaan selisih energy yang tinggi terhadap elevasi puncak pada bendung yang terpilih dan juga elevasi muka air disawah yang tertinggi dan keperluan energy dalam membawa air yang sudah sesuai. Dalam perencanaan bendung sungai, termasuk didalamnya direncanakan ruang olak atau kolam olak yaitu salah satu kelengkapan bagian hilir bendung yang berfungsi untuk meredam energi yang ditimbulkan oleh aliran dengan kecepatan besar sebagai akibat dari peninggian taraf muka air udik oleh pemBendung.

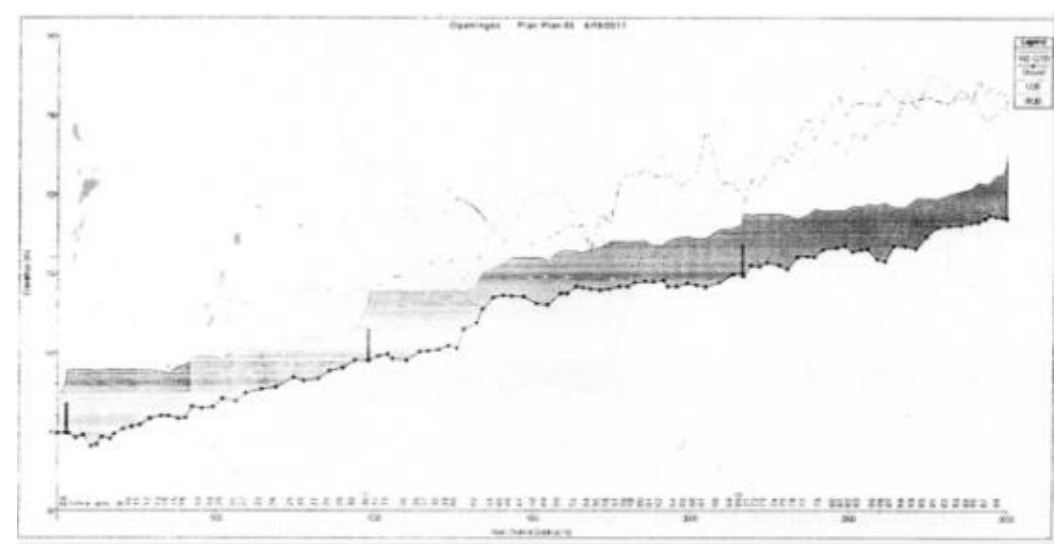

Gambar 7 : Long Section Kondisi dengan Bangunan Q100 Sungai Cipamingkis

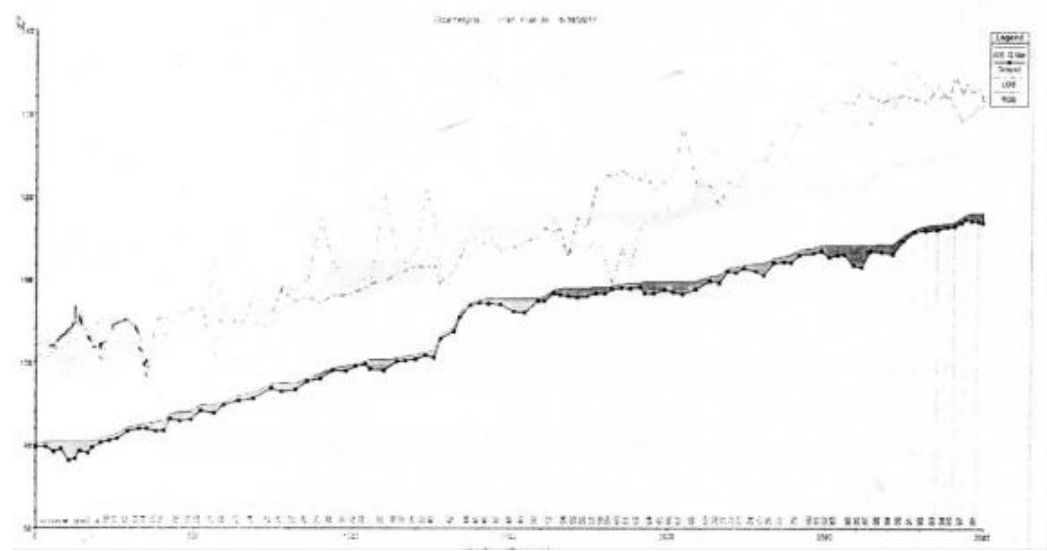

Gambar 8 : Long Section Kondisi Eksisting $Q=10 \mathrm{~m} 3 /$ det Sungai Cipamingkis 
Perhitungan kedalaman gerusan Lokal untuk tanah berpasir Menurut Lacey :

Rumus :

$\mathrm{ds}=0.473(\mathrm{Q} / \mathrm{f})^{1 / 3}$

Dimana :

$$
\begin{aligned}
\mathrm{ds}= & \text { Kedalaman penggerusan } \\
\mathrm{Q}= & \text { Nilai Debit aliran }\left(\mathrm{m}^{3} / \mathrm{det}\right) \\
\mathrm{f}= & \text { Faktor dari silt }=1.76 \mathrm{D}^{0,5} \\
\mathrm{D}= & \text { Diameter kebersamaan atau mayoritas } \\
& (\mathrm{mm})
\end{aligned}
$$

Perhitungan :

Debit $=158.067 \mathrm{~m}^{3} / \mathrm{det}=1.05 \mathrm{~m}^{3} / \mathrm{det} / \mathrm{m}$

Diameter $=0.5 \mathrm{~m}$

$$
\begin{aligned}
\mathrm{F} & =1.76(0.5)^{0,5}=1.2445 \\
\text { Ds } & =0.47(1.05 / 1.2445)^{1 / 3} \\
& =0.44 \mathrm{~m}
\end{aligned}
$$

\section{Hasil Analisa Faktor Kehancuran Bendung Pengaruh Akibat Dari Kondisi Tofografi Sungai Cipamingkis.}

Dengan Kondisi kemiringan slope dasar saluran Sungai yang curam dan debit banjir yang besar sehingga potensi menjadi aliran kritis dan menyebabkan banyaknya material sedimen dasar berupa pasir dan batuan yang bergerak oleh besarnya aliran yang tertahan, hal tersebut sehingga menjadi Gerusan Local (Lokal Scoring) aliran yang berputar didasar sungai yang dapat menimbulkan keruksakan di hilir olakan bendung, tanah tanggul bantaran retak dan terkikis erosi.

\section{Terjadinya Rebesan disekitar Bangunan}

Perkolasi atau rembesan air tanah dari pada daerah sekitar bangunan diakibatkan adanya beda tinggi energi dibangunan tersebut. Jalur rembesan yang mungkin terjadi :
A) jalur rembesan dibawah pada bangunan

B) jalur rembesan disepanjang sisi pada bangunan.

Adanya perkolasi menyebabkan :

a) Tekanan yang ke atas (statik)

b) Erosi pada bawah tanah/piping (konsentrasi aliran menyebabkan hilangnya bahan)

c) Tekanan aliran (dinamik)

Terjadinya akan rembesan tersebut dapat membahayakan kestabilitas bangunan. Ada beberapa cara yang dapat digunakakan untuk melindungi bangunan dari bahayanya erosi bawah tanah, Pada dasarnya banyak bangunan yang akan menggunakan beberapa kombinasi konstruksi bendung.

Hal utama yang dipertimbangkan untuk terhidara dari erosi bawah tanah yaitu dengan mengurangi kehilangan beda tinggi energi per satuan panjang pada setiap jalur rembesan dan ketidakterusan (discontinuities) pada garis tersebut.

Proses pada perencanaan bangunan, pemilihan konstruksi-konstruksi lindung dapat digunakan masing-masing atau dikombinasi oleh :

- lantai hulu

- dinding halang

- filter pembuang

- konstruksi pelengkap.

Perlu diketahui bahwa erosi bawah tanah merupakan masalah tiga dimensi dan bahwa tiap konstruksi lindung harus bekerja ke setiap arah dan maka dari itu termasuk dalam pangkal bendung (abutment) dan bangunan pengambilan.

Jalur rembesan akan memperpanjang lantai 
hulu. Diakibatkan dari gaya tekan ke atas pada bawah lantai diimbangi dengan tekanan air yang diatasnya, menyebabkan lantai dapat dibuat tipis. Hal yang terpenting yaitu bahwa lantai kedap air, dan juga sambungannya dengan badan bendung. Sifat kedap air dapat dicapai dengan foil platic/lempung kedap air yang dibawah lantai dan terdapat pada sekat karet yang menghubungkan antara lantai dan badan bending

Faktor utaman penyebab runtuhnya pada konstruksi tersebut berbahaya pada penurunan yang tidak merata (diferensial) antara lantai dan badan bendung. Maka dari itu sambungan perlu dirancang dan dilakukan dengan hatihati.

Lantai tersebut dapat dibuat dari beton bertulang pada ketebalan $0.10 \mathrm{~m}$, atau pasangan batu dengan tebal $0.20-0.25 \mathrm{~cm}$. sangat penting untuk menggunakan sekat air dari karet yang tidak akan rusak akibat adanya penurunan tidak merata

Keuntungan dari pembuatan lantai hulu yaitu biayanya lebih murah dibandingkan dengan dinding halang vertikal yang dalam, karena yang terakhir ini memerlukan pengeringan dan penggalian. Namun sebagaimana sampaikan oleh Lane dalam teorinya, bahwa panjang horizontal pada rembesan yaitu tiga kali dan juga kurang efektif dibanding dengan panjang vertikal yang panjangnya sama.

\section{Analisis Kestabilan Konstruksi Bendung}

Mengetahui konstruksi bangunan cipamingkis kondisi yang tidak kuat,dan rusak berat karena bendung tersebut tidak kuat menahan gaya yang dipengaruhi oleh beban dan tekanan sehingga bisa mengangkat dan mendorong tubuh bendung tersebut dan dapat mengalami perubahan terhadap stabilitasnya konstruksi yang ada.

Analisa stabilitas yang diperhitungkan :

a. Stabilitas Terhadap Guling

b. Stabilitas terhadap Geser

c. Stabilitas terhadap daya dukung tanah

Kondisi tersebut diperhitungkan dan dilihat pada keadaan :

1. Kondisi Air pada saat normal, tanpa adanya sedimen

2. Kondisi Air pada saat normal,tanpa adanya sedimen

3. Kondisi banjir,sedimen penuh, kondisi gempa.

Cek kontrol Gaya guling terhadap kestabilitas:

- Dalam Keadaan Normal

$$
\mathrm{SF}=\mathrm{Mr} / \mathrm{Mo}>1,5
$$

- Dalam Keadaan Gempa $\mathrm{SF}=\mathrm{Mr} / \mathrm{Mg}>1,3$

Dimana :

$\mathrm{SF}=$ Nilai Keamanan

$\mathrm{Mr}=$ Momen tahan

$\mathrm{Mg}=$ Momen Guling

Cek Gaya Geser :

- Keadaan Normal $\mathrm{Sf}=\left(\mathrm{f} . \sum \mathrm{V} / \sum \mathrm{H}>1.5\right)$

- Keadaan Gempa : $\mathrm{Sf}=\left(\mathrm{f} \cdot \sum \mathrm{V} / \sum \mathrm{H}>1.5\right)$ 
Dengan :

$\mathrm{f}=$ Nilai Koefisien geser $(\operatorname{tg} \phi)$

$\sum \mathrm{V}=$ Banyaknya Gaya Vertikal

$\sum \mathrm{H}=$ Banyaknya Gaya Horizontal

\section{KESIMPULAN}

1. Hasil analisa kerusakan bahwa lokasi bendung sebelumnya, rencana untuk bendung baru lokasinya harus pindah ke lokasi hulu bendung lama yang relatip mempunyai dasar saluran datar dengan mempertimbangkan elevasi intake untuk muka saluran irigasi, dan bangunan bendung yang lama diusulkan diperbaiki kembali menjadi sebagai bangunan Groundshill untuk menahan arus kecepatan air. Pertimbangan terhadap desain lama harus dirubah dengan memperhitungkan bagian gaya-gaya yang mempengaruhi kestabilan bendung, boor pile dan kualitas beton sebagai pertimbangannya.

2. Mencegah dan melarang adanya galian untuk mengeruk material yang ada disepanjang sungai dan bertambah jumlah penduduk sehingga mengakibatkan adanya alih fungsi lahan yang dapat mempengaruhi kestabilan kondisi sungai.

\section{DAFTAR PUSTAKA}

[1] Maryono, "Penelusuran, Sudetan dan Pembuatan Tanggul Sungai Justru Menyebabkan Banjir Besar," Artikel Pada Harian Kompas, 2001.

[2] Suripin, Pelestarian Sumber Daya Tanah dan Air. Yogyakarta, 2004.

[3] CD. Soemarto, Hidrologi Teknik, , 2nd ed. Jakarta: Penerbit Erlangga, 1995.

[4] Mulyanto, Sungai, Fungsi dan Sifatsifatnya, 1st ed. Yogyakarta: Graha Ilmu, 2007.

[5] Yusuf, dkk Gayo, Perbaikan dan Pengaturan Sungai. Jakarta: PT. Pradnya Paramita, 2008.

[6] B Sekaran, Research Methods For Business, John Wiley and Sons Inc, Eds. New York, USA: A Skill Building Aproach, 2003.

[7] I., Kuswaya, W Wardhani, Materi Pokok Penelitian Tindakan Kelas, 1st ed. Banten: Universitas Terbuka, 2014.

[8] Sugiyono, Metode Penelitian Pendidikan Pendekatan Kuantitatif, Kualitatif dan $R \& D$. Bandung: Alfabet, 2014.

[9] Sugiyono, Metode Penelitian Kuantitatif Kualitatif dan $R \& D$ Bandung: Alfabeta, 2013.

[10] Sugiyono, Statistika Untuk Penelitian. Bandung: Alfabeta, 2010. 